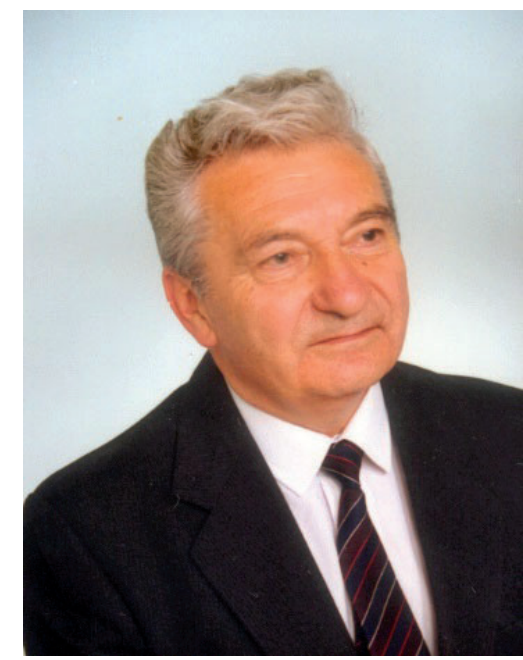

\title{
THE MEMORY OF THE SENIOR POLISH GRAVITATIONAL MEDICINE ABOUT HIS WORK AT THE MILITARY INSTITUTE OF AVIATION MEDICINE IN WARSAW
}

Mieczysław WOJTKOWIAK

Source of support: Own sources

Author's address: M. Wojtkowiak, Warsaw, Poland, e-mail: pjambp@wiml.waw.pl

Abstract: The author, a pilot and aviation doctor, recalls the 60 years of work at the Military Institute of Aviation Medicine in Warsaw. An overview of scientific and application works, which contributed to the development of aviation medicine, is presented. Special emphasis has been placed on research activities related to the influence of impact accelerations on animals and humans. The author discusses in detail the methods of research of pilots in overload centrifuges and their dynamics of changes in connection with the development of modern jet aircraft and space science. For health reasons, prof. Mieczysław Wojtkowiak's work was developed by dr. Rafał Lewkowicz on the basis of scientific articles written by M. Wojtkowiak, associates and personal conversations with him.

Keywords: acceleration tolerance, animal centrifuge, human centrifuge 
"I was born in the year in which our Institute was founded. Perhaps this coincidence has made me associated with MIAM since 1957, allowing me to make my dreams come true".

\section{MY WORK FOR AVIATION MEDICINE IS THE PASSION}

Aviation became my passion at an early age. In 1939, I witnessed an air combat in the early days of World War II. This was the moment when my passion for flying and the desire to learn it were born. After the World War II, as the Poznań Flying Club was reactivated, it became my first aviation training center.

Following fast-track completion of Karol Marcinkowski Secondary School in Poznań, I received a matriculation certificate in 1948. In the same year, I started medical studies at the Faculty of Medicine of the Medical Academy of Poznań. In studyfree time, I continued aviation training on gliders and powered planes available at the Flying Club. As a result of my aviation activity, I obtained qualifications and a certificate of a glider and powered aircraft pilot as well as a certificate of the secondclass parachute jumper.

In 1950, I was employed as an assistant at the Department of Physiology of the Medical Academy of Poznań, giving lectures and teaching classes to medicine and dentistry students while also holding the duties of a tutor for student groups. I also continued aviation training at the Poznań Flying Club. Being aware of my interests in aviation, my superior, professor Edward Czarnecki, decided to pursue aviation medicine-related subjects at the Department of Physiology of the Medical Academy of Poznań. To this end, I established collaboration with the Director of the Central Institute of Medical Examinations for Aviators in Warsaw, professor Władysław Okniński, and in 1950 I was sent there for my aviation medicine training. While still a student, I completed a course in aviation medicine which was my first contact with this field of medicine. By that time, I had already become a fully qualified aviator. My teachers included professor Stanisław Marczewski, an ophthalmologist professor Władysław Pol, and other specialists employed at the institute. I retook this course in 1952 and obtained the befitting certificate. Staying at the Institute deepened my interest in aviation physiology. Having obtained the knowledge in aviation medicine, I was fully prepared for education at the Medical Academy of Poznań.
/Prof. Mieczysław Wojtkowiak, MD/

After I completed the studies and received my degree in medicine in 1953, I was drafted for military service. Following the necessary military training, I was appointed a senior physician at the Military Academy in Legnica. After one year's service at this position, owing to my aviator qualifications and by the decision of the Commander of the Air Force Medical Service, col. Bielicki, and the Air Force Commander, gen. Turkiel, I was transferred to continue service in the Air Force. In 1955, I became a senior physician of the Aviation Training Regiment at Krzesiny. There, having received the approval of the Air Force Commander, gen. FreyBielecki, I underwent aviation training on JAK-18, JAK-12, JAK-11 and TS-8 planes and obtained the military pilot certificate. Most of my flights were performed on TS-8 BIES planes. During my duty at Krzesiny, besides conducting routine examinations of the aviation personnel, I also carried out my first research studies involving the analysis of physical burden of pilots at different flight conditions, mostly in relation to pre- and post-task reaction times.

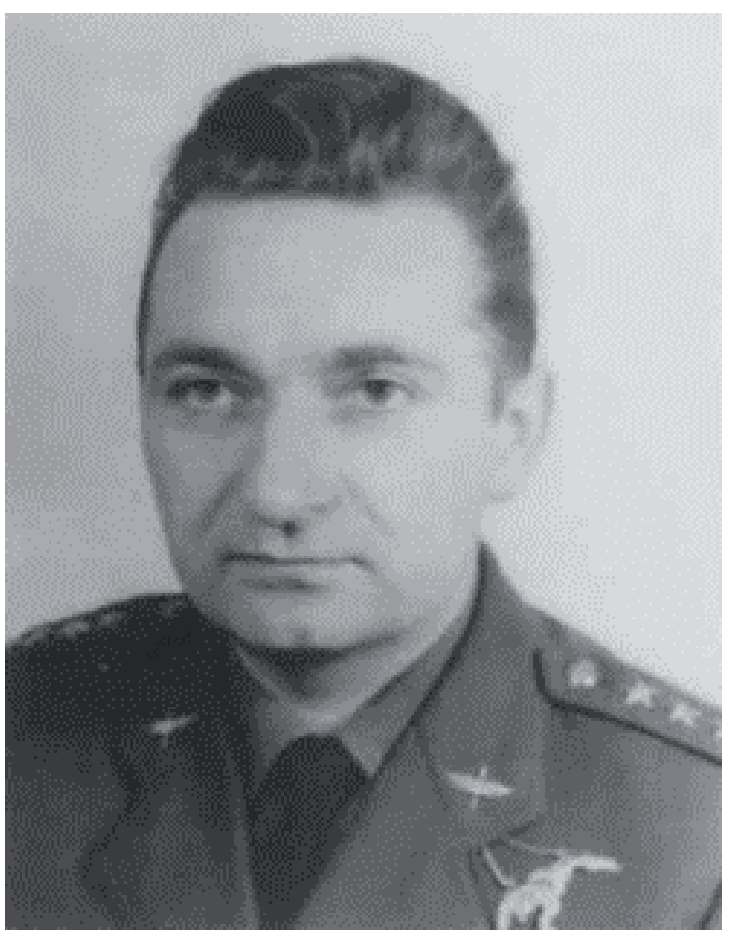

Fig. 1. Lieutenant pilot Mieczysław Wojtkowiak. 
Finally, in 1957, having obtained practical expertise in the medical service at the air force, I started my research career at the Central Institute of Medical Examinations for Aviators in Warsaw (currently the Military Institute of Aviation Medicine) as a senior assistant at the Department of Physiology. Two years later I was appointed an Associate Professor at the Aviation Pathophysiology Division. In the same year, I obtained the second-degree medical specialization in aviation medicine and started my medical researches. One of my first research concerned the effects of acceleration on biological structures with special reference to the changes of body parameters [18]. It was an assessment of the respiratory tract functioning, especially a fundamental parameter, i.e. Tissular Respiratory Index, being a very sensitive indicator of the metabolic disorders. Ultracentrifuge used for the organic mixture fractional separation, being able to generate several thousand rotations per minute, was applied for investigations of the gas exchange in the isolated hepatic tissue under the action of +40 to $+8000 \mathrm{Gz}$.

In 1965, I obtained M.D., PhD. in philosophy from the Scientific Board of the Medical Academy of Warsaw having defended my doctoral dissertation titled Selected physiological reactions in pilots subjected to in-training punchouts. This way I started my scientific career in MIAM, which I developed for the next half of century. During this time, my scientific interest and studies focused on the following four subject groups:

1. Studies on the effects of short-term acceleration occurring during emergency and training ejections.

2. Studies on the physiological reactions of humans and animals to various types of acceleration.

3. The search for novel methods for examination and assessment of systemic tolerance to acceleration.

4. The use of physical factors and physiological reactions to increase the systemic tolerance to acceleration.

\section{VERY SHORT-DURATION ACCELERATIONAS AN IMPORTANT PROBLEM OF EXPERIMENTAL INVESTIGATIONS}

The first subject group consists of the studies of the effects of short-time acceleration occurring during ejections on pilots' bodies. In these studies, first of this type to be conducted in Poland, T. Jasiński (psychologist), T. Drobisz (engineer) and I focused on physiological and psychological reactions of humans subjected to high acceleration $[16,27,52,78]$. As the results of the studies, we observed a num- ber of changes related to the reactions within the cardiovascular system and the release of catecholamines and 17-ketogenous steroids due to excessive stimulation of the sympathetic nervous system. The conclusions of the studies conducted together with Z. Podgórski and J. Domaszuk were presented in numerous publications $[42,52,67,82]$. As shown by the findings presented therein, even short-duration acceleration stimulates the pituitary-adrenal hormonal axis, largely dependent on the accompanying stimulatory excitations and emotions. Notably, the increase in hemodynamic reactions and hormonal secretion is a good indicator of psychological excitation in emergency situations, also in flight situations.

Significant emotional excitations of subjects provided the ground for introduction of emergency ejection trainings to prepare pilots for abandoning their planes in a safe manner. Being the only Polish researcher authorized to perform ejection trainings, I personally conducted all tests using the training ejection device. I was also the first subject, who ejected himself $18 \mathrm{G}$ with a full cartridge gunpowder, from a newly developed ejection device UTKZ.

Another article published by the same group [69], focusing on the distribution of body centers of gravity in relation to the G-force vectors, was of particular theoretical as well as practical importance. Together with the co-authors, I determined the pilot body positions which, when adopted in the ejection seat, may result in the risk of spinal injuries. This study, which received the third-degree prize in the research competition announced by the Minister of Defense served as the basis for my expert's opinion on the changes introduced to the design of ejection seats in training devices.

Also of practical importance were the results of studies carried out together with T. Jasiński and S. Szajnar [31,32,76], concerning optimization of the ejection process, as it was demonstrated that the efficiency of the seat ejection system could be improved in relation to the conventional solutions. In the studies, we presented a method for solving the problem of reduction of gravitational forces experienced by the pilot during the seat ejection phase.

Further conducted scientific assessment of the effects of impact of $\mathrm{G}$-forces upon rapid restrainment falls from height in the devices aimed at preventing falls of humans working on elevated structures. I also analyzed the risks of spinal fractures due to improperly worn harness gear. These studies were conducted in collaboration with the occupational safety experts of the Central Institute 
for Labor Protection in Łódź. Moreover, together with J. Domaszuk, A. Truszczyńska and R. Lewkowicz, I also studied the issue of spinal pains in pilots and the methods to prevent them $[11,34,35,87,89]$.

\section{SLOWLY INCREASED AND EXTENDED ACCELERATIONS AS A NEW RESPONSIBLE CHALLENGE}

The second group of studies focused on the reactions of humans $[80,81]$ and animals $[17,68,90]$ to various acceleration conditions. Most of these studies were team efforts of numerous authors studying these problems worldwide. A number of hemodynamic, electrophysiology, radiology, radioisotope and morphological methods were applied in these studies. Most studies focused on hemodynamic disturbances due to blood flowing in the direction of the G-force vectors and to the stasis of blood within the vessels, organs, and tissues.

As far as animal studies are concerned, worthy of note was the introduction of a new Polish centrifuge for animals (fig. 2a) with the feature of liquid nitrogen-freezing of animals subjected to acceleration. I was also involved in the development of the guidelines regarding the technical requirements of this centrifuge. Introduction of the animal centrifuge made it possible to conduct studies on animal tissues and organs which are inaccessible in case of human studies. The methodology of the studies consisted in determination of the location of intravenously administered isotopes and the assessment of this location in organs and tissues (fig. 2).

Studies conducted in collaboration with S. Barański, Z. Edelwejn, Jurczak, Czerski, Domaszuk and Stojanowski involved examination of Wistar rats (fig. 3) in various experimental settings $[1,3,12,56,85]$. This allowed for determination of hemodynamic disturbances resulting from acceleration of varied durations; the results of the animal studies were published as scientific articles $[6,7,8,9,18,53]$. The aforementioned studies allowed for the formulation of following conclusions:

- In centrifuge settings, displacement of systemic fluids and proteins of varied molecular mass occurs as confirmed by isotopic examinations [3,9];

- In repeated experiments involving long durations of exposure to G-forces, capillary hypertrophy and dilation of extracellular spaces occur together with an increase in permeability of vascular walls resulting in morphological changes within the muscles, kidneys and liver as confirmed by isotopic assays following prolonged hypodynamia $[7,8]$;
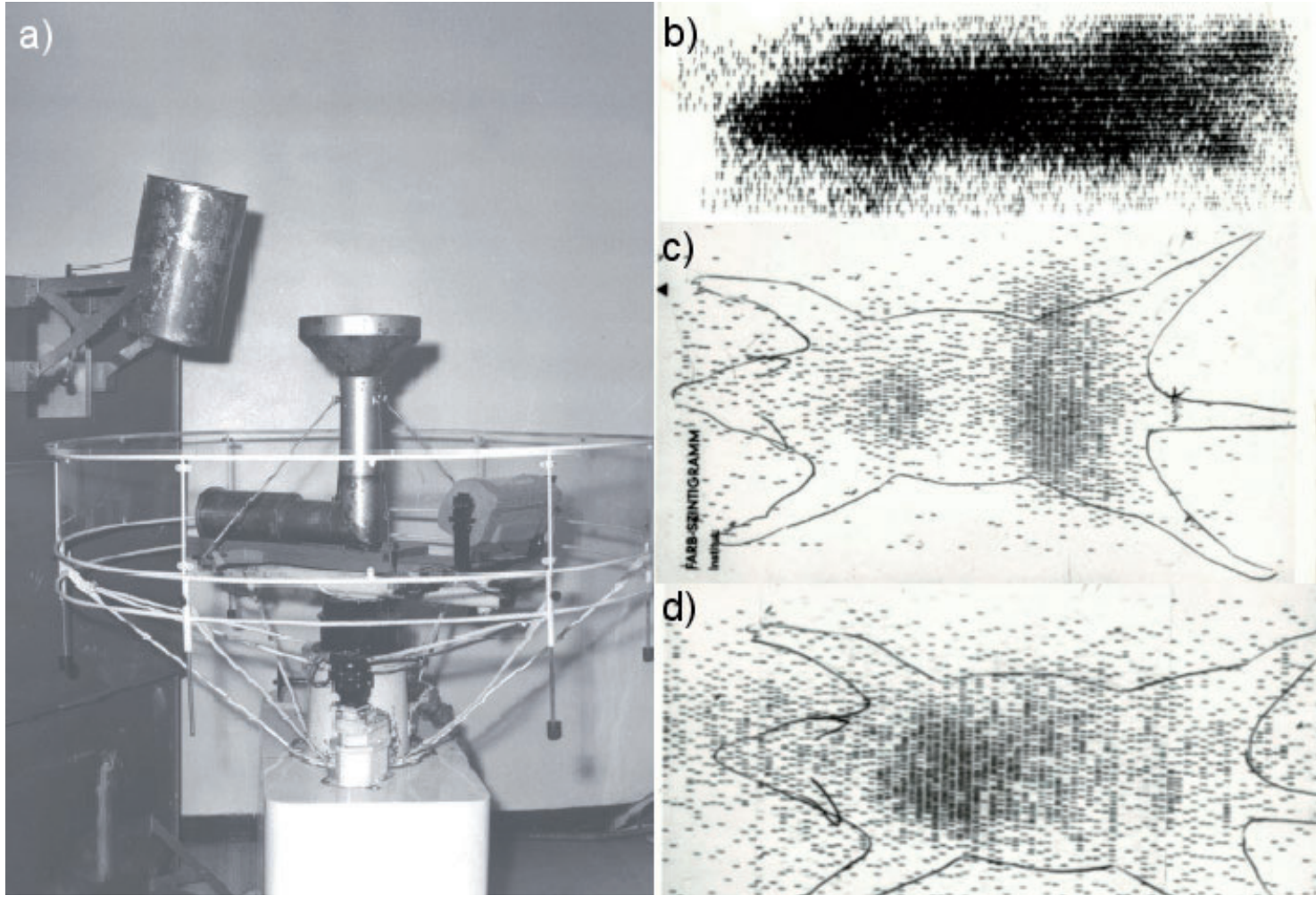

Fig. 2. a) The animal centrifuge (examination of rats following intravenous administration of radioisotopes in an isotonic solution); b) Administration of radioactive sodium (22Na); c) apparent blood displacement (131l-albumins) in simulated zero-gravity conditions; $d$ ) caudal dislocation of blood ( $51 \mathrm{Cr}$-globulin) under a directional gravitational force. 


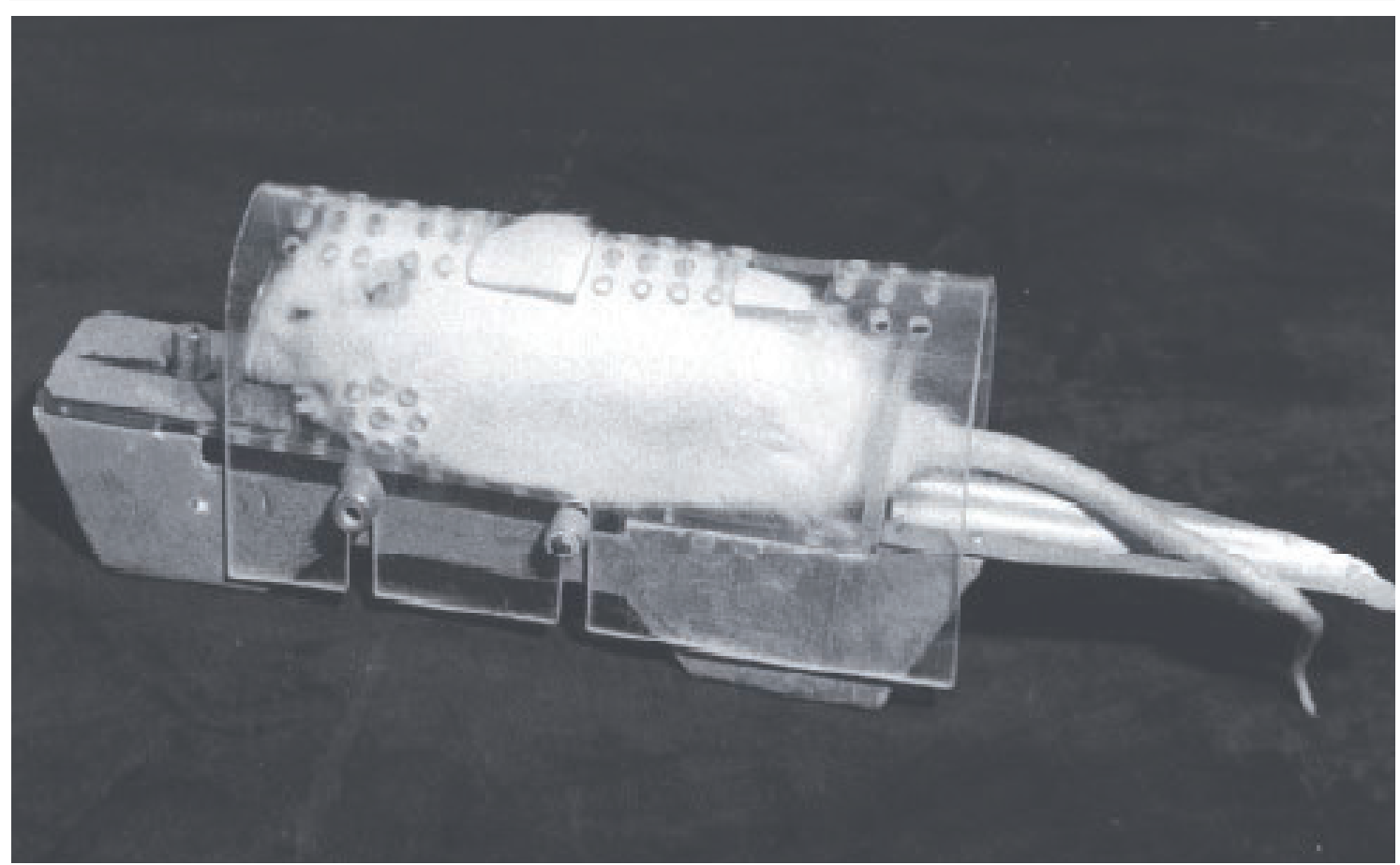

Fig. 3. Rat placed in the animal centrifuge cabin cage.

- Change in rat's position involving pelvis being elevated at an angle of 30 degrees led to prolonged hypodynamia imitating zerogravity conditions, muscle ischemia and plethora of the organs within the upper part of the body. The disturbances in the muscular circulation in limbs are maintained much longer than those within the kidneys, liver and brain; on the other hand, no dilation of capillaries occurs in pulmonary circulation;

- Hemodynamic and bioelectric disturbances within the skeletal muscles as observed upon centrifugation are much stronger when observed after long-term hypokinesis (fig. 3).

The behaviors of the circulatory system exposed to extreme acceleration exceeding the maximum tolerance of humans were also studied in aggressive baboon monkeys (fig. 4). The studies were carried out in collaboration with Z. Edelwejn who assessed the brain function. The objective of those studies was to assess the behavior of the circulatory system after the maximum tolerance of acceleration manifested by G-force induced loss of consciousness (G-LOC). Therefore, it was interesting to study the changes in the function of the circulatory system increasing up to the threshold of animal's death. After resuscitation, the circulatory function went back to normal. The acceleration used in the studies was adequate to those used in the line training of pilots, thus confirming the epistemic value of these studies of extreme circulatory disturbances that occur following a prolonged loss of consciousness.

The analysis of changes in circulatory function in the critical phase was particularly valuable as it allowed for the assessment of the heart resilience. Results of studies [14] conducted together with Z. Edelwejn and K. Kwarecki allowed to monitor hemodynamic disturbances increasing in proportion to the acceleration. This practical aspect of the results consisted in the gravitational force exposure program corresponding to the characteristics of stimuli used in the evaluation of acceleration limits in pilots [10].

The analyses of cardiac arrhythmias in pilots undergoing human centrifuge evaluations may also be included in this group of studies $[15,21,29,83,90]$. In collaboration with German researchers: W. Papenfuss, G. Kollande, D. Wirth and G. Ponisch $[30,41,77]$, I proposed a classification of this types of disturbances including their incidence rates and described their importance in aviation medicine certifications. Similar studies were conducted in cooperation with L. Kopka [20] in a group of 80 pilots, five of which experienced a G-LOC. Physiological changes observed in these pilots were described in detail via cardiological analysis to observe that the behavior of the cardiovascular system during the centrifuge tests depended largely on the status of the autonomic nervous system.

Rapid changes of potentials within the system observed during the tests in the conditions of cardiac ischemia are very valuable for the assessment 
of the efficiency of the electrical conduction system of the heart. In addition, we observed that a reduction in the heart rate occurring already at the increasing G-force phase is a signal of disturbed compensation capabilities of the electrical conduction system and an indication for immediate discontinuation of the test.

In another studies conducted together with $\mathrm{E}$. Marks, W. Zużewicz [29] as well as with G. Ponish and D. Wirth $[51,83]$, we observed that the principal cause of arrhythmias occurring during the exposure to acceleration consists in rapid changes in the potential within the autonomic nervous system and that, in subsequent trials, even when conducted in the same subjects, the G-force stimulus does not stimulate the system in the same manner. One of the conclusions drawn from these studies is that higher accelerations are tolerated by pilots with hyperactive and intermediate type of parasympathetic nervous system.

An example record of physiological parameters measured to determine the limits of tolerance to acceleration presented in fig. 5 includes the following standard parameters: ECG, respiratory wave, acceleration curve and time of response to visual stimulus appearing within the peripheral visual field. It should be noted that fig. 5 also presents newly introduced physiological measurement param-

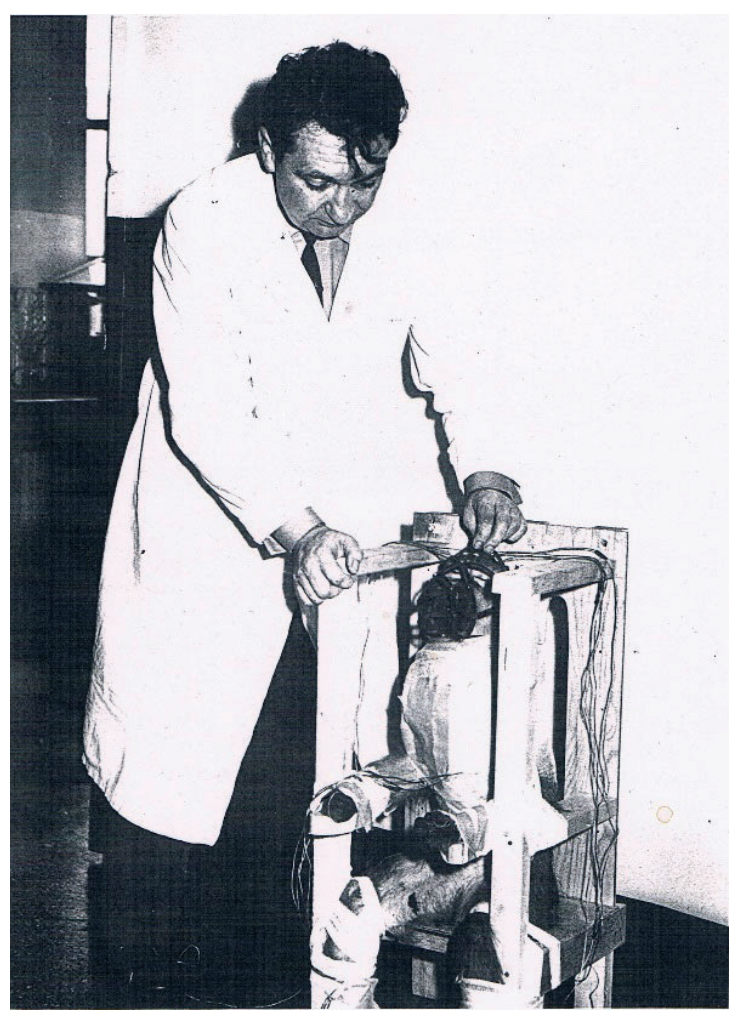

Fig. 4. A Baboon being prepared for examination in the animal centrifuge. eters such as the temporal artery blood flow rate assessed by Doppler ultrasonography.

The use of a proprietary Doppler method for the measurement of temporal artery blood flow rates in subjects tested in the human centrifuge $[45,48,62]$ allowed for precise identification of the moment when visual disturbances occurred. The moment of change in the direction of the blood flow is marked on the mean flow rate curve. The time span of the change in the direction of the blood flow measured until the disappearance of momentary flow pulsation indicated the time until the loss of peripheral vision. The moment of disappearance of momentary flow pulsation indicated the acceleration tolerance limit. Also is the phase of centrifuge deceleration when venous flow rapidly returns into the vascular system of the head.

The developed method for the assessment of tolerance to acceleration allowed for full objectivization of hitherto subjective evaluation of results, thus facilitating unquestionable identification of simulating or dissimulating subjects [46]. Due to the long time span between the start of blood outflow within the temporal artery and the loss of peripheral vision, the method increased the safety of centrifuge tests by preventing G-LOC cases. fig. 6 presents the instrumentation and the technique for the Doppler probe used to measure the flow of blood within the temporal artery being mounted on the subject's head [84].

Other studies in this group were related strictly to ophthalmological issues $[23,24,25,36,37,38,44,72]$. Principally, they pertained to two important directions of research. The first direction, pursued together with I. Kożuchowska and J. Tajchert, involved isotopic verification of the impact of sudden dislocations of large blood volumes on intraocular pressure and on the permeability of the blood-ocular barrier for blood proteins [25]. The other direction of research, pursued together with I. Kożuchowska and J. Zawitkowski [23,24,72], was aimed at elucidation of the role of intraocular pressure in the development of visual disturbances that always preceded the loss of consciousness in routine trials. The results of these studies partially explained the role of intraocular pressure in the development of visual disturbances while also pointing to the possibility of G-LOC occurring without preceding visual disturbances in pilots with low intra-ocular pressure. Other studies that may be included in this group were biochemical analyses of blood at variable acceleration. 


\section{HUMAN CENTRIFUGE STUDIES}

The third subject group consists of studies devoted to the development of methodologies of human centrifuge tests for aviation personnel and to the assessment of the results of these tests. As part of this group of studies, and in collaboration with T. Jasiński, I analyzed the relationships between the age and morphotic features of pilots and the limits of tolerance to acceleration $[40,54,58,75]$. These studies were of considerable epistemic value. Of particular note is the practical applicability of these studies in routine tests of the aviation personnel with the aim of determining the limits of systemic endurance and for medical certification-related purposes. These studies $[20,61]$ facilitated an objective assessment of compensatory reactions within the circulatory system in various in-flight conditions, thus providing a potential basis for routine diagnostic examinations of pilots. Articles on the subject were published in Polish as well as international journals $[5,22,30,41,43,59,60,70,77]$. In these studies, conducted together with B. Bembnowski, A.P. Kotovskaya, S. Barański, W. Papenfuss and G. Kollande, we described e.g. the human centrifuge tests using three different acceleration programs. The first program, referred to as the linear program, facilitated precise determination of acceleration at which visual disturbances resulting from the reduced pressure within the ocular artery are observed. The second program, referred to as the temporal program, allows for the assessment of the duration of the efficiency of compensatory mechanisms of the circulatory system while the third program, referred to as the interval program, exposes subjects to conditions similar to those experienced during the flight with regard to compensation of rapidly increasing multidirectional accelerations.

Following appropriate verification and determination of grading scales, the developed programs $[43,70]$ were introduced to routine examinations of the aviation personnel. Of particular importance was the development of a visual field meter facilitating the assessment of visual perception within the peripheral field upon the exposure to acceleration (in collaboration with Wołkanowski) [91]. The first visual field meter facilitated the assessment of peripheral perception of light stimuli traveling along the arms at stochastic speeds until the loss of peripheral vision indicative of the limit of tolerance to acceleration. Introduction of the second visual field meter was aimed at determination of the peripheral perception of stationary objects changing their shapes until the loss of curricu- peripheral vision and the lack of response to the shape changes. The aforementioned visual field meters were used in my collaborations with $O$. Truszczyński and R. Z. Lewkowicz $[33,39,70]$ aimed at the assessment of the effects of acceleration of various characteristics on simple reaction times in pilots.

\section{METHODS OF INCREASING TOLERANCE TO ACCELERATION}

The fourth subject group consists of studies $[2,26,28,50,65,71,74,86,88]$ on the applicability of certain forms of physical training for increasing the systemic tolerance to acceleration. This group also includes the studies [13] conducted together with Z. Dziuk and H. Sulajnis regarding the assessment of correlations between the development of selected motor abilities and the tolerance to acceleration.

Together with B. Bembnowski, M. Błaszczakiewicz and H. Aremba [4], I demonstrated that, among the different training devices used to increase the tolerance to in-flight conditions, looping exercises are too burdensome for the cardiovascular system and therefore their intensity should be reduced.

The tolerance of a trained body to acceleration depends to some degree on the motor skills developed during the training, including strength, speed, or speed-endurance [13] which improve the tolerance to acceleration. Exercises aimed at the development of the aforementioned motor skills were included in the physical education curricula of pilot candidates of the Polish Air Force Academy in Dęblin (PAFA) and became a compulsory element of training for pilots undergoing annual trainings a Military Training and Fitness Centers (MTFC). The developed training program consisted of 2 stages. The first stage consisted in isometric training of selected muscle groups along with respiratory exercises and maximum muscle straining [79]. The second stage consisted in conducting of type L1 circorespiratory trials to increase the blood pressure in coordination with muscle straining and increasing acceleration within a centrifuge [47]. These forms of training turned out to be an efficient method for significant enhancement of tolerance to slowly and rapidly increasing acceleration.

The tolerance to acceleration was the major problem at the time of the first space flights, and therefore the training I held together with Jan Marks at MTFC was aimed at increasing this tolerance. Krzysztof Klukowski was responsible for 

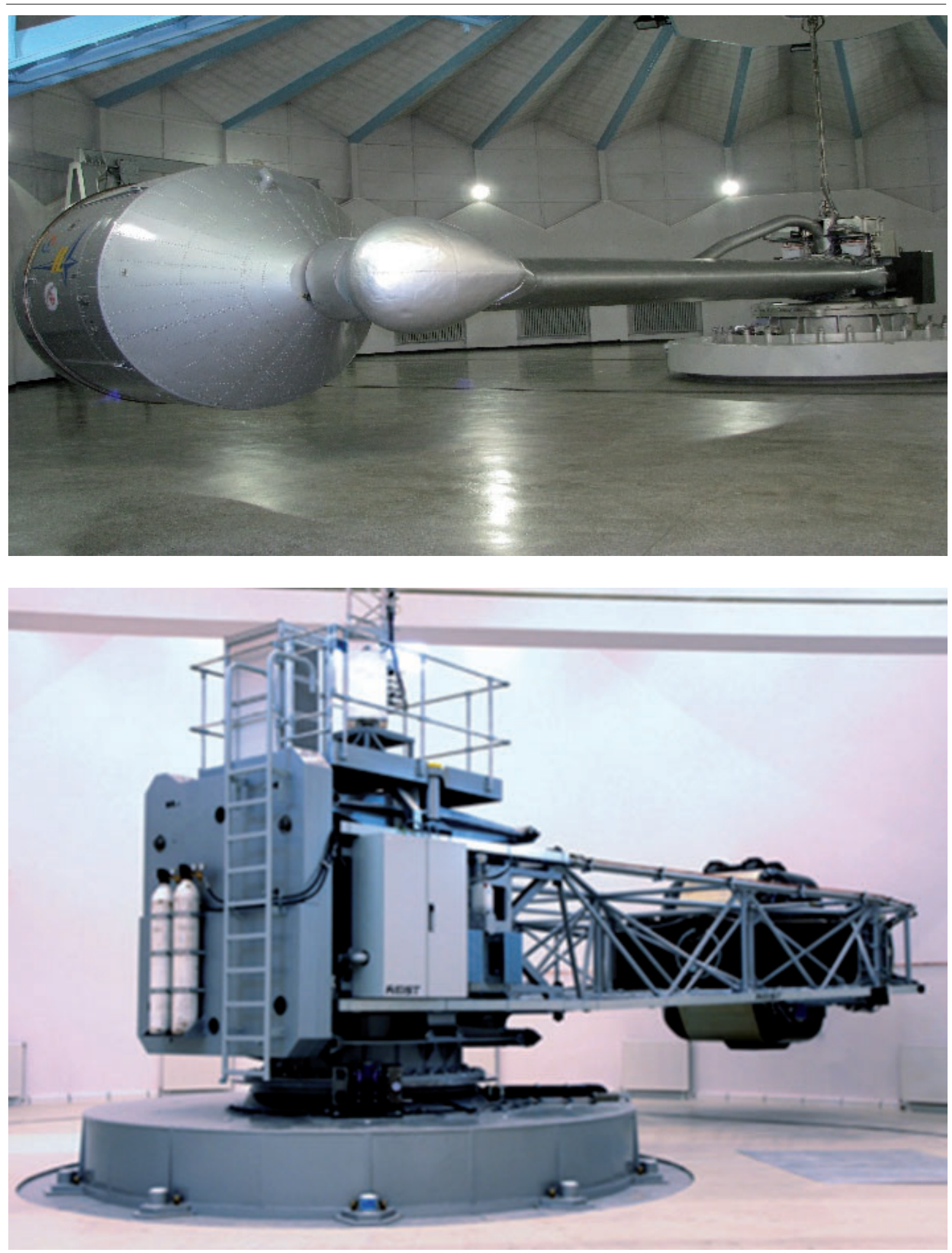

Fig. 5. Old and new centrifuge for people in MIAM.

coordination of the entire specialized training and the program of selection of candidates. The exercise program included individual gymnastic elements verified at PAFA. Following appropriate physiological elaboration of each exercise, the exercise set was introduced into the pilot train- ing curriculum at MTFC. The results of physiological studies carried out at MTFC were published in [55], with the general forms of physical and fitness training described by dr. Jan Marks. Let me also mention that I also took part in the program for the selection of the first Polish cosmonaut [66] 
as regarded the assessment of the candidates' tolerance to acceleration. The $\mathrm{G}$-force tolerance tests were conducted in the MIAM's human centrifuge.

The assessment of physical fitness indicators for use in aviation performed together with Z. Jethon, Z. Sarol and Z. Dziuk [19] showed that the Crampton's indicator and Skibinski circo-respiratory indicator were sufficient for determination of adjustment to hypoxic conditions while the Mondurant index was sufficient for determination of G-force compensation. Maximum systemic tolerance to acceleration depends on the age and body structure and is observed in pilots below the age of 38 , with lowest values being observed in tall and lean individuals [54]. Studies on the methods of increasing the tolerance to acceleration also included the tests of anti-gravity suits of various designs aimed at protecting individuals from the effects of $\mathrm{G}$-forces [30,49,57,63,64]. In years 20022006, as part of my collaborations with W. Papenfuss, G. Kollande, G. Ponish and D. Wirth of the German Air Force Institute of Aviation Medicine in Königsbrück, I studied the effectiveness of LIBELLE hydrostatic anti-G suit. In this period, I conducted periodic health examinations of German pilots, assessing their G-force tolerance limits using a Polish human centrifuge. Similar studies were conducted in collaboration with W. Albery and S. Bolia as part of individual research contract for joint Polish-American studies on the efficacy of various types of anti-gravity apparel $[63,64,73]$.

During the near 60 years of my employment at the MIAM, I gained rich experimental as well as medical experience in examinations of various types of consequences of acceleration and other conditions exerted on living organisms during continuous or periodic exposure of humans and animals in centrifuges. As the result of my scientific works in 1982, by the decision of the Scientific Council of the MIAM and on the basis of my previous research accomplishments and the dissertation entitled Studies of the systemic tolerance to gravity loads as assessed by means of temporal artery blood flow rates and the visual disturbances, I received habilitation in medical sciences. Nine years later, in 1993, I obtained the title of the Professor of Medical Science.

\section{MY OTHER SCIENTIFIC ACTIVITY}

Parallel to my research activity mentioned above, I was involved in numerous additional scientific task. In years 1977-78, I was delegated to Iraq, where I worked for a year and a half as an expert and lecturer in aviation medicine. Being an experienced specialist, particularly in the pathophysiology of accelerations, I engaged in consultations and collaborations with researchers from the USSR, German Democratic Republic, Bulgaria, and Czechoslovakia. I systematically broadened my scientific knowledge during numerous international research internships. In the same period, I was appointed by professor H. Bjurstedt (Karolinska Institutet, Department of Environmental Physiology) a corresponding expert of the International Union of Physiological Sciences, Commission on Gravitational Physiology.

Since 1982, I was a member of the Scientific Council of the MIAM in Warsaw. Besides my affiliation at the Institute, I was also an active member of numerous scientific associations. In 1962, I joined the Polish Astronautical Society, where I served as the head of the Bioastronautics Committee, treasurer, secretary general, and vice-president. In 1964, I joined the Polish Physiological Society and in 1989, the Polish Ergonomics Society. Since 1988, I was a member of the International Astronautical Federation and the International Academy of Astronautics as well as the scientific consultant of the Central Institute for Labor Protection. In addition, I was a member of the Commission of Astronautics and Space Technologies at the Committee on Space and Satellite Research of the Polish Academy of Sciences and as well as a member of the Commission of Space Biology and Medicine of this Committee. I was also a member of the State Commission on Aircraft Accidents Investigation.

Since the beginning of my work at the Institute, I conducted trainings to physicians applying for specialization in aviation medicine (lectures and training of physicians studying to obtain the first and second degree specialty in aviation medicine) as well as lectures and simulator trainings for the aviation personnel. I supervised the specialist trainings of about 50 physicians.

I was a reviewer of numerous aviation-related studies and doctoral dissertations. In years 19801990, I was a scientific expert involved in consultations concerning certain modifications in the design of pilot's ejection seat. I also assessed prototypes and ergonomic properties of THL helmets. I was the author of technical and medical guidelines for the new human centrifuge which was installed at the MIAM.

I received numerous awards and distinctions for my research and educational achievements, including: in the period of 1962-1990: first-degree prize in the research competition of the Minister of Defense for the study of spinal injuries in pilots 
undergoing emergency ejections in 1973, seconddegree prize for research on the effect of gravitational loads on the visual system in pilots in 1976, third-degree prize for co-authoring of a handbook titled "Medycyna Lotnicza i Kosmiczna" ("Aviation and Space Medicine") in 1977 and a honorary distinction for the study involving the measurements of blood flow rate in the assessment of systemic tolerance to gravitational loads in 1980.

Moreover, I received four awards of the Commander of Air Force for my research studies and involvement in aviation, eight prizes in research competitions held by the MIAM, as well as the award of the editors of the "Lekarz Wojskowy" ("Military Physician") journal for my study entitled Respiration of isolated liver tissues under gravitational loads of $40-8000 \mathrm{G}$. Furthermore, I received the second prize of the 33rd Convention of Polish Ophthalmologists for my study entitled Pneumotonographic assessments in orthostatic tests conducted in pilots before and after the effects of gravitational load.

For my achievements in research and educational work, I was awarded with:

- Gold Medal of the Armed Forces in the Service of the Fatherland (1973);

- Gold Cross of Merit (1978);

- Knight's Cross of the Order of Polonia Restituta (1985);
- Medal of the Commission of National Education (1988);

- Gold Medal of Merit for National Defense (1986);

- Medal of Merit for National Anti-Aircraft Defense (1987);

- Medal of Merit for Air Forces (1989) as well as other medals.

In addition, I was awarded the Badge for Outstanding Health Service Work and the Honorary Badge of the Polish Red Cross.

I was an active participant of numerous symposia as well as scientific conferences and congresses both in Poland and abroad. My professional achievements include a total of 129 publications in Polish and international journals as well as several textbook chapters. In years 1963 to 1993, I conducted about 15,000 examinations and trainings of pilots using human centrifuges and I was an instructor at about 1,200 ejections performed using land training devices at acceleration of 9-16G.

As a professional soldier, and later as a scientific consultant, I worked for the MIAM until the end of 2015. I wish the MIAM the best of luck in the next 90 years and more, and I would like to thank people who I worked with for our Institute for the last sixty years.

\section{TECHNICAL ASSISTANCE:}

Rafał Lewkowicz

\section{AUTHORS' DECLARATION:}

Study Design: Mieczysław Wojtkowiak; Data Collection: Mieczysław Wojtkowiak; Manuscript Preparation: Mieczysław Wojtkowiak. The Author declares that there is no conflict of interest.

\section{REFERENCES}

1. Barański S, Edelwejn Z, Wojtkowiak M. Hemodynamic and bioelectric disturbances in striated muscles of rats subjected to accelerative forces after a period of hipokinesia. Space Live Science. 1970; 2:400-3.

2. Barański S, Markiewicz L, Wojtkowiak M, Sokołowski E. The role of physical training in increasing + Gz tolerance in the initial phase of aviation training. The Physiologist. 1988; 51:24-27.

3. Barański S, Wojtkowiak M. Badania przemieszczania się białek osocza krwi u szczurów poddanych działaniu przyspieszeń. Postępy Astronautyki. 1970; 11:5-13.

4. Bembnowski B, Błaszczakiewicz M, Wojtkowiak M, Zaremba H. Obraz radiologiczny i elektrokardiograficzny serca po działaniu przyspieszeń występujących podczas ćwiczeń na lopingu. Medycyna Lotnicza. 1965; 18:5-13.

5. Bembnowski B, Wojtkowiak M, Chojnacki A. Der Einfluss der Beschleunigung in der Achse Gz auf das rontgenologische Bild des Herzens und der Lungengefasse bei Flugzeugfuhrern mit verminderter Beschleunigungstoleranz. Zeitschrift fur Militarmedizin. 1982; 1:9-11. 
6. Czerski P, Wojtkowiak M. Distribution of body fluids in rats under the in $\neg$ fluence of acceleration. Some problems of aviation and space medicine. Praga: Charles University. 1967:61-3.

7. Czerski P, Wojtkowiak M, Zaremba H. Functional and morphological studies of small and medium blood vessels in rats exposed to prolonged intermittent +3 Gz acceleration. Patologia Polska. 1967; 3/4:395-405.

8. Czerski P, Wojtkowiak M, Zaremba H. Radioizotopowe i morfologiczne badania nad wpływem wielokrotnego działania przyspieszeń na małe naczynia krwionośne. Medycyna Lotnicza. 1967; 22:139-41.

9. Domaszuk J, Wojtkowiak M. Ocena zachowania się naczyń włosowatych podczas działania przyspieszenia. Postępy Astronautyki. 1976; 3:73-80.

10. Domaszuk J, Wojtkowiak M. Wniezapnaja potiera soznania u lotczikow s niskim wnutrigłaznym dawleniem wo wremia diejstwia pieregruzok. Kosm. Biologia I Awiacjonnaja Medicina. 1977; 3:86-7.

11. Domaszuk, J, Wojtkowiak M. Wpływ przyspieszeń +Gz na powstawanie dolegliwości bólowych kręgosłupa. Postępy Astronautyki. 1987; 20:37-43.

12. Domaszuk J, Wojtkowiak, M, Janusewicz M. Zachowanie się niektórych wskaźników biochemicznych we krwi szczurów podczas badania tolerancji przyspieszeń +Gz według różnych programów. Postępy Astronautyki. 1977; 2:83-91.

13. Dziuk Z, Sulajnis H, Wojtkowiak M. Ocena współzależności między znoszeniem przyspieszeń w osi +Gz, wynikami prób czynnościowych a rozwojem wybranych cech motorycznych. Postępy Astronautyki. 1969; 4:49-56.

14. Edelwejn Z, Kwarecki K, Wojtkowiak M. Wpływ ekstremalnych przyspieszeń na czynność bioelektryczną ośrodkowego układu nerwowego i serca oraz zmiany morfologiczne narządów wewnętrznych u małp. /in Russian/. Medycyna Lotnicza. 1973; 43:125-37.

15. Gembicka D, Wojtkowiak M, Kuzak W. Zachowanie się wybranych parametrów biochemicznych we krwi oraz częstości skurczów serca u ludzi poddawanych działaniu wolno i szybko narastających wielokrotnie powtarzanych przyspieszeń. Medycyna Lotnicza. 1990; 108/109:11-17.

16. Jasiński T, Tomczak A, Wojtkowiak M. Pomiar wybranych wskaźników fizjologicznych i psychologicznych podczas katapultowania treningowego. In Rakowski A, Chodała A, Kalina RM. Sporty ekstremalne w przygotowaniu żołnierzy i formacji antyterrorystycznych. Warszawa: Polskie Towarzystwo Naukowe Kultury Fizycznej. 2003; 6:63-72.

17. Jendyk M, Wojtkowiak M. Działanie przyspieszeń i podwyższonej temperatury na przemianę węglowodanową u świnek morskich. Medycyna Lotnicza. 1969; 30:51-60.

18. Jendyk M, Wojtkowiak M. Oddychanie izolowanych tkanek wątroby w warunkach działania przyspieszeń 40-8000 G. Lekarz Wojskowy. 1962; 5:411-20.

19. Jethon Z, Sarol S, Dziuk Z, Wojtkowiak M. Wartość wybranych wskaźników kondycji fizycznej w lotnictwie. Wychowanie Fizyczne i Sport. 1964; 3:327-35.

20. Kopka L, Wojtkowiak M. Zachowanie się układu krążenia w okresie utraty świadomości podczas badań na wirówce przeciążeniowej. Medycyna Lotnicza. 1981; 4(73):1-8.

21. Kopka L, Wojtkowiak M, Markiewicz L, Dabrowa R, Bulski W. Kliniczne i orzeczniczo - lekarskie aspekty niektórych zaburzeń rytmu serca podczas działania przyspieszeń w osi +G. Medycyna Lotnicza. 1990; 108/109:18-28.

22. Kotowskaja AP, Barański S, Gembicka D, Wojtkowiak M, Will-Wiliams IF, Kokowa HI. Powyższenie ustojcziwosti czełowieka k pieregruzkam naprawieni gołowa-taz /+Gz/ putiem uwieliczenia urownia gidratacji. Kosmiczeskaja Biologia i Awiokosmiczeskaja Medicina. 1987; 6:14-8.

23. Kożuchowska I, Wojtkowiak M. Badania pneumotonograficzne w próbie ortostatycznej u pilotów przed i po działaniu przyspieszenia. Medycyna Lotnicza. 1977; 57:7-14.

24. Kożuchowska I, Wojtkowiak M. Ocena zaburzeń ciśnienia śródgałkowego w następstwie działania przyspieszeń u pilotów poddawanych badaniom w wirówce przeciążeniowej. Medycyna Lotnicza. 1978; 58:7-16.

25. Kożuchowska I, Wojtkowiak M, Tajchert J. Wpływ zaburzeń hemodynamicznych spowodowanych działaniem przyspieszeń na rozmieszczenie „J albuminy w gałce ocznej zwierząt doświadczalnych. Klinika Oczna. 1975; 45:437-42.

26. Kubiczkowa J, Wojtkowiak M, Jaskowski A. Wydolność układu równowagi a tolerancja przyspieszeń. Medycyna Lotnicza. 1990; 108/109:6-10.

27. Markiewicz L, Sokołowski E, Wojtkowiak M. Praca pilota w hełmie THL i fotelu katapultowym. Ergonomia. 1990; 13:103-12.

28. Markiewicz L, Wojtkowiak M, Stehni P. Wpływ ćwiczeń na symulatorze małych wartości przyspieszeń dośrodkowych na poziom tolerancji przyspieszenia. Medycyna Lotnicza. 1985; 86:1-6.

29. Marks E, Zużewicz W, Wojtkowiak M. Typ reakcji wegetatywnej a tolerancja na przyspieszenia. Postępy Astronautyki. 1980; 4:7-19.

30. Papenfuss W, Barański S, Kollande G, Wojtkowiak M. Ergebnisse von Untersuchungen zur Uberlastungstoleranz bei Flugzeugfuhrern mit Abweichungen im Gesundheitszustand. Zeitschrift fur Militarmedizin. 1986; 4:147-9. 
31. Szajnar S, Wojtkowiak M. Biodynamiczne i optymalizacyjne aspekty katapultowania w procesie opuszczania samolotu. Postępy Astronautyki. 1991; 25:103-18

32. Szajnar S, Wojtkowiak M. Wybrane problemy bezpieczeństwa załogi statku powietrznego w sytuacjach awaryjnych. Warszawa: BIL-GRAF S.c. 1999.

33. Truszczynski O, Lewkowicz R, Wojtkowiak M, Biernacki MP. Reaction time in pilots during intervals of high sustained G. Aviat Space Environ Med. 2014; 85(11):1114-20.

34. Truszczyńska A, Lewkowicz R, Truszczyński O, Wojtkowiak M. Back pain and its consequences among Polish Air Force pilots flying high performance aircraft. Int J Occup Med Environ Health. 2014; 27(2):243-51.

35. Truszczyńska A, Lewkowicz R, Truszczyński O, Wojtkowiak M, Rąpała K. Back pain in Polish military helicopter pilots. International Journal of Occupational Medicine and Environmental Health. 2012; 25(3):258-64.

36. Truszczyński O, Wojtkowiak M, Biernacki MP, Kowalczuk K. The Effect of Hypoxia on the Critical Flicker-Fusion threshold in Pilots. International Journal of Occupational Medicine and Environmental Health. 2009; 1(22):13-8.

37. Truszczyński O, Wojtkowiak M, Biernacki M, Kowalczuk K, Lewkowicz R. Effect of high acceleration exposure on visual perception in Polish pilots measured with critical fusion frequency test (CFFT). Polski Przegląd Medycyny i Psychologii Lotniczej. 2012; 18(1):19-27.

38. Truszczyński O, Wojtkowiak M, Kowalczuk K, Biernacki MP, Lewkowicz R. Percepcja wzrokowa u pilotów w warunkach niedotlenienia wysokościowego. Polski Przegląd Medycyny Lotniczej. 2010; 16(2):141-9.

39. Truszczyński O, Wojtkowiak M, Lewkowicz R, Biernacki MP, Kowalczuk K. Reaction time in pilots at sustained acceleration of +4.5 Gz. Aviat Space Environ Med. 2013; 84:845-9.

40. Więckowski Sz, Kowalczuk K, Wojtkowiak M. Badania granicy tolerancji przyśpieszeń w wirówce u podchorążych WSOSP w latach 2007/2008 w porównaniu do lat 1994-2000. Polski Przegląd Medycyny Lotniczej. 2009; 4:405-12.

41. Wirth D, Wojtkowiak M, Ponisch G, Victor F. Zur Vorhersage der Uberlastungsvertraglichkeit /+Gz/ ein Beischpiel fur die Moglichkeit der medizinischen Beurteilung der Leistungsfahigkeit des Menschen unter extremen Umweltabedinungen durch die mathematische Modellbildung. Zeitschrift fur Militarmedizin. 1981; 2:89-90.

42. Wojtkowiak M. Adaptacja ustroju do działania przyspieszeń w katapultowaniu rzeczywistym i pozorowanym. Lekarz Wojskowy. 1971; 1:40-5.

43. Wojtkowiak M. Assessment of tolerance limits in subjects tested on human centrifuge. Artificial Satellites. 1976; 11:29-35.

44. Wojtkowiak M. Badania histologiczne gałek ocznych zwierząt doświadczalnych poddanych działaniu przyspieszeń. Postępy Astronautyki. 1977; 2:71-81.

45. Wojtkowiak M. Badania nad przydatnością fali tętna rejestrowanej z płatka usznego dla oceny granicy tolerancji przyspieszenia. Medycyna Lotnicza. 1991; 3:110.

46. Wojtkowiak M. Badania tolerancji ustroju na działanie przyspieszeń na podstawie oceny prędkości przepływu krwi w tętnicy skroniowej i zaburzeń wzrokowych. Medycyna Lotnicza. 1982; 77:1-9.

47. Wojtkowiak M. Ćwiczenia fizyczne przygotowujące pilotów do wykonywania prób krążeniowo-oddechowych zwiększających tolerancję przyspieszenia. Postępy Astronautyki. 1989; 22:83-94.

48. Wojtkowiak M. Elektrody uciskowe do rejestracji elektrokardiogramu w warunkach dynamicznych. Medycyna Lotnicza. 1988; 101:22-5.

49. Wojtkowiak M. Fizjologiczne i fizyczne sposoby zwiększania tolerancji przyspieszeń. In Bień M. 40 lat Ludowego Wojska Polskiego. Warszawa: Zakład Narodowy im. Ossolińskich. 1984:620-5.

50. Wojtkowiak, M. Human centrifuge training of men with lowered +Gz acceleration tolerance. The Physiologist. 1991; 34:80-2.

51. Wojtkowiak M. Mechanizmy fizjologiczne występujące podczas działania przyspieszeń w osi +Gz. Medycyna Lotnicza. 1984; 83:26-33.

52. Wojtkowiak M. Niektóre odczyny fizjologiczne pilotów podczas ka`tapultowania treningowego. Medycyna Lotnicza. 1965; 34:89-93.

53. Wojtkowiak M. Normalisation of hemodynamic changes caused by action of prolonged acceleration in rats. Life Science and Space Res. Berlin: Akademie-Verlag. 1974; 12:103-106.

54. Wojtkowiak M. Poziom tolerancji na przyspieszenia w zależności od wieku i niektórych cech morfotycznych badanych. Postępy Astronautyki. 1975; 1:49-60.

55. Wojtkowiak M. Przygotowanie kondycyjne pilotów zwiększające tolerancję przyspieszeń. Postępy Astronautyki. 1989; 22:119-27.

56. Wojtkowiak M. Rozmieszczenie płynów ustrojowych u szczurów poddawanych działaniu przyspieszeń w osi +Gz. Postępy Astronautyki. 1969; 4:131-7. 
57. Wojtkowiak M. Rozwój badań nad zwiększeniem skuteczności ubiorów przeciwprzeciążeniowych. Polski Przegląd Medycyny Lotniczej. 2003; 2:185-04.

58. Wojtkowiak M. Selected problems of space medicine. Early physiological research at the Military Institute of Aviation Medicine. Pol J Aviat Med Psychol. 2013; 19(3):37-44.

59. Wojtkowiak M. The application of blood flow velocity measurement under the influence of $+G z$ acceleration. Adv. Physiol. Sci. 1981; 19:273-7.

60. Wojtkowiak M. The effect of emotional stress prior to the onset of centrifugation on acceleration tolerance in pilots. The Physiologist. 1983; 26:161-3.

61. Wojtkowiak M. Wpływ przyspieszeń /+Gz/ na zachowanie się wybranych wskaźników układu krążenia u pilotów badanych w wirówce przeciążeniowej. Postępy Astronautyki. 1984; 17:63-81.

62. Wojtkowiak M. Wykorzystanie pomiaru szybkości przepływu krwi w badaniach tolerancji ustroju na wirówce przeciążeniowej. Medycyna Lotnicza. 1980; 66:15-20.

63. Wojtkowiak M, Albery W, Bolia S, Domin A. Badania porównawcze ubiorów przeciwprzeciążeniowych w wirówce polskiej. Polski Przegląd Medycyny Lotniczej. 2006; 3(12):227-37.

64. Wojtkowiak M, Albery W, Bolia S, Domin A. Comparative research on different anti - g suits tested in polish human centrifuge. Survival and Flight Equipment Association Congress in Warsaw14-17.03.2006.

65. Wojtkowiak M, Biernacki M. Comparison of the results of ATL and respiratory parameters before and after the anti-G training. Pol J Aviat. Med. Psychol. 2013; 19(1), 5-12.

66. Wojtkowiak M, Domaszuk J. Kryteria doboru załóg lotniczych i kosmicznych. Postępy Astronautyki. 1991; 24.

67. Wojtkowiak M, Domaszuk J. Metody i ocena badań tolerancji przyspieszeń na wirówce przeciążeniowej. Medycyna Lotnicza. 1974; 46:31-39.

68. Wojtkowiak M, Domaszuk J. Skojarzone działanie przyspieszeń i podwyższonej temperatury na przemianę węglowodanową mózgu świnek morskich. Postępy Astronautyki. 1974; 2-3:69-75.

69. Wojtkowiak M, Domaszuk J. Wpływ pozycji pilota na urazy kręgosłupa podczas katapultowania. Medycyna Lotnicza. 1973; 42:5-13.

70. Wojtkowiak M, Domaszuk J. Wpływ przedłużonych przyspieszeń na czas reakcji wzrokowo-ruchowych. Medycyna Lotnicza. 1974; 44:89-93.

71. Wojtkowiak M, Domaszuk J, Janusewicz M. Wpływ treningu fizycznego specyficznego i niespecyficznego na poziom tolerancji przyspieszeń +Gz u szczurów. Postępy Astronautyki. 1977; 2:93-7.

72. Wojtkowiak M, Domaszuk J, Zawitkowski J. Zachowanie się ciśnienia śródgałkowego u pilotów poddawanych działaniu przyspieszeń w osi +Gz. Medycyna Lotnicza. 1975; 47:39-45.

73. Wojtkowiak M, Domin A. Badania porównawcze ubiorów przeciw przeciążeniowych w wirówce polskiej. Polski Przegląd Medycyny Lotniczej. 2006; 3:227-35.

74. Wojtkowiak M, Jasiński T. Przygotowanie fizyczne pilotów wojskowych w aspekcie tolerancji na przyspieszenia. In Chodała A, Klimczak J, Rakowski A, eds. Trening Militarny Żołnierzy. Szczytno: Wyższa Szkoła Policji. 2006; 119-127.

75. Wojtkowiak M, Jasiński T, Domin A, Kowalczuk K. Analiza badań granic tolerancji przyspieszeń w latach 1994-2000. Polski Przegląd Medycyny Lotniczej. 2002; 8:4-10.

76. Wojtkowiak M, Jasiński T, Kowalczuk K. Analiza katapultowań w aspekcie przyczyn i występowania obrażeń ciała w lotnictwie polskim w latach 1988-1998. Polski Przegląd Medycyny Lotniczej. 2002; 8:361-7.

77. Wojtkowiak M, Kollande G. Untersuchungen der Reaktionszeit als Indikator der Uberlastungstoleranz. Zeitschrift fur Militarmedizin. 1989; 6:264-6.

78. Wojtkowiak M, Malewicz H, Stojanowski Z, Drobisz T. Badania odczynów ustroju występujących podczas katapultowania treningowego. Medycyna Lotnicza. 1967; 23:5-19.

79. Wojtkowiak M, Markiewicz L. Znaczenie treningu izometrycznego w poprawie tolerancji przyspieszeń w osi +Gz. Medycyna Lotnicza. 1989; 102:50-6.

80. Wojtkowiak M, Mikuliszyn R. Skojarzone działanie na pilota przyspieszeń o zmiennych kierunkach. Przegląd Sił Powietrznych. 2004; 12:25-7.

81. Wojtkowiak M, Mikuliszyn R. Skojarzone działanie różnokierunkowych przyspieszeń na ustrój pilota stwarzanych przez samoloty o zmiennych ustawieniach dysz wylotowych. Polski Przegląd Medycyny Lotniczej. 2008; 3:277-81.

82. Wojtkowiak M, Podgórski J. Wpływ katapultowania treningowego na UTKZ na układ moczowy. Medycyna Lotnicza. 1971; 34:89-93. 
83. Wojtkowiak M, Ponisch G, Wirth D. Występowanie skurczów dodatkowych serca w czasie działania przyspieszeń $+\mathrm{Gz}$ na wirówce ludzkiej i ich znaczenie w ocenie orzeczniczo-lekarskiej. Medycyna Lotnicza. 1974; 46:7-18.

84. Wojtkowiak M, Rowicki T. Adaptacja aparatu ULP-10 do badań w warunkach dynamicznych na wirówce przeciążeniowej. Medycyna Lotnicza. 1980; 66:21-26.

85. Wojtkowiak M, Stojanowski Z, Domaszuk J. Wpływ przyspieszeń + Gz na poziom sodu, potasu i wapnia w surowicy krwi. Medycyna Lotnicza. 1974; 43:15.

86. Wojtkowiak M, Truszczyński O, Kowalczuk K. Set of exercises increasing acceleration tolerance in the high performance aircraft pilots. Physical Education and Sport. A Quarterly Journal of Physical Education and Physical Activity Sciences. 2006; 50:261-267.

87. Wojtkowiak M, Truszczyński O, Lewkowicz R. Back pain in polish military transport aircrafts pilots. Polski Przegląd Medycyny i Psychologii Lotniczej. 2012; 18(1):7-17.

88. Wojtkowiak M, Truszczyński O, Mikuliszyn R. Special Leibesübungen für die erhóhung der beschleunigungs toleranzgrenzen bei den flugzeugführer. 50 Międzynarodowe Spotkanie Robocze Lekarzy Lotniczych Niemieckich Sił Powietrznych połączone z 42 rocznicą Niemieckiego Towarzystwa Medycyny Lotniczej i Kosmicznej. 09-12.09.2004 Furstenfeldbriick. Materiały Militar Insititut fur Luftfahrtmedizin.

89. Wojtkowiak M, Zakrzewska E. Wpływ przyspieszeń na powstawanie bólu szyi u pilotów samolotów myśliwskich i śmigłowców. Polski Przegląd Medycyny Lotniczej. 2009; 15(4):421-33.

90. Wojtkowiak M, Zakrzewska E. Review of the studies on the experimental animals undergoing acceleration in the Polish centrifuges in the Military Institute of Aviation Medicine. Polski Przegląd Medycyny i Psychologii Lotniczej 2012; 18(3):51-64.

91. Wołkanowski M, Truszczyński 0, Wojtkowiak M. New method of visual disturbances assessment in pilots during the tests in the Polish human centrifuge. Int J Occup Med Environ Health. 2007; 20(1):44-7.

Cite this article as: Wojtkowiak M. The Memory of The Senior Polish Gravitational Medicine about His Work at The Military Institute of Aviation Medicine in Warsaw. Pol J Aviat Med Bioeng Psychol 2017; 23(3-4): 36-49. DOI: 10.13174/pjambp.20.12.2018.07 